\title{
Combination treatment for type 2 diabetes mellitus (T2DM): dipeptidyl peptidase-4 inhibitors (DPP-4) and metformin
}

\author{
Erna Kristin* \\ Department of Pharmacology and Therapy, Faculty of Medicine, Universitas Gadjah Mada, \\ Yogyakarta
}

DOI: http://dx.doi.org/10.19106/JMedSci00403201701

\begin{abstract}
Using the concept of inhibition of dipeptidyl peptidase-4 (DPP-4) as a new treatment for type 2 diabetes mellitus (T2DM) is based on the inhibition of bioactive peptide inactivation process. Most clinical trials on DPP-4 inhibition are based on vildagliptin, sitagliptin, saxagliptin, and linagliptin. The drugs may improve glycemic control when they are given as a combination with other oral hyperglycemic agents or when they are given to patients who received metformin and still had inadequate glycemic control. Studies showed that vildagliptin was well-tolerated if it was given as add-on treatment to metformin for 24 weeks duration. In addition, vildagliptin showed significant clinical improvement proven by the associated decrease in $\mathrm{HbA} 1 \mathrm{c}$ and fasting glucose levels. Sitagliptin in initial combination therapy with metformin decreased HbA1c level by $2.1 \%$ after 24 weeks of treatment. It was reported that DPP-4 inhibitor saxagliptin increased glycemic control when it was added to metformin. The study included 743 patients with an average $\mathrm{HbA} 1 \mathrm{c}$ level of $8.0 \%$ when they were treated with metformin alone. After 24 weeks of treatment, saxagliptin decreased $\mathrm{HbA} 1 \mathrm{c}$ level by $0.7 \%$. A multicenter, randomized, placebo-controlled, double-blind, parallel-group study examined the efficacy and tolerability of linagliptin as treatment adjunctive to metformin in patients T2DM. The primary end point was changed in $\mathrm{HbA} 1 \mathrm{c}$ from baseline to 24 weeks of treatment. The mean adjusted change from baseline in $\mathrm{HbA} 1 \mathrm{c}$ in the linagliptin group was $0.49 \%$ compared with an increase of $0.15 \%$ in the placebo group, with $26 \%$ and $9 \%$ of participants in the linagliptin and placebo groups, respectively, achieving an $\mathrm{HbA} 1 \mathrm{c} 7.0 \%$ at 24 weeks. The combination of DPP-4 inhibitors and metformin has been shown to be well-tolerated with a very low risk of hypoglycemia. Therefore, DPP-4 inhibitors and metformin combination is an efficient, safe, and well-tolerated therapy for T2DM.
\end{abstract}

\section{ABSTRAK}

Konsep penghambatan terhadap dipeptidyl peptidase-4 (DPP-4) sebagai obat baru untuk diabetes mellitus tipe 2 (DMT2) didasarkan pada penghambatan proses inaktivasi peptida bioaktif. Sebagian besar uji klinis penghambat DPP-4 dilakukan menggunakan vildagliptin, sitagliptin, saxagliptin, dan linagliptin. Obat tersebut dapat memperbaiki kontrol glikemik jika diberikan dalam kombinasi dengan antidiabetes oral lainnya atau jika diberikan kepada pasien yang menerima metformin dan kontrol glikemik tidak memadai. Uji klinik menunjukkan bahwa vildagliptin dapat ditoleransi dengan baik jika diberikan sebagai 
obat tambahan pada metformin selama 24 minggu. Selain itu vildagliptin menunjukkan perbaikan klinis bermakna yang dibuktikan dengan penurunan $\mathrm{HbA} 1 \mathrm{c}$ dan kadar glukosa puasa. Sitagliptin sebagai obat tambahan pada metformin menurunkan $\mathrm{HbA} 1 \mathrm{c}$ sebesar $2,1 \%$ setelah 24 minggu pengobatan. Dilaporkan bahwa penghambat DPP-4 saxagliptin sebagai obat tambahan pada metformin meningkatkan kontrol glikemik. Penelitian ini melibatkan 743 pasien dengan $\mathrm{HbA} 1 \mathrm{c}$ rata-rata $8,0 \%$ saat pasien diobati dengan metformin saja. Setelah 24 minggu pengobatan, saxagliptin menurunkan $\mathrm{HbA} 1 \mathrm{c}$ sebesar $0,7 \%$. Uji klinik multisenter, acak terkendali dengan kontrol plasebo, tersamar gada secara paralel dilakukan untuk mengkaji efikasi dan tolerabilitas linagliptin sebagai obat tambahan metformin pada pasien DMT2. Luaran utama adalah perubahan HbA1c antara sebelum dan sesudah pengobatan selama 24 minggu. Rerata penurunan $\mathrm{HbA} 1 \mathrm{c}$ dari data awal pada kelompok linagliptin adalah $0,49 \%$ dibandingkan dengan kenaikan $0,15 \%$ pada kelompok plasebo, dengan berturut-turut $26 \%$ dan $9 \%$ pasien yang diberi linagliptin dan plasebo mencapai $\mathrm{HbA} 1 \mathrm{c} 7,0 \%$ setelah 24 minggu. Kombinasi penghambat DPP-4 dan metformin terbukti ditoleransi dengan baik dengan risiko hipoglikemia sangat rendah. Oleh karena itu, kombinasi penghambat DPP-4 dan metformin efektif, aman dan ditoleransi dengan baik untuk terapi DMT2.

Keywords: DPP-4 inhibitor - sitagliptin - vildagliptin - saxagliptin - linagliptin - metformin - type 2 diabetes mellitus

\section{INTRODUCTION}

It has been known that the duration and level of hypoglycemia in type 2 diabetes mellitus (T2DM) are associated with the risk of complications. ${ }^{1}$ Therefore, glycemic control should be achieved for the prevention of cardiovascular and microvascular complications. The change in lifestyle, namely diet control and physical activity, is the main aspect in the treatment. However, in most patients, pharmacological intervention is needed, where metformin is the first line treatment. Metformin is a relatively cheap agent which mechanism of action is decreasing glucose significantly in T2DM patients. $^{2}$ Metformin acts mainly through the inhibition of glucose degradation process in the liver. ${ }^{3}$ Metformin also increases insulin sensitivity in the liver and muscle, ${ }^{4}$ inhibits intestinal glucose absorption, ${ }^{5}$ and increases plasma GLP-1 level. ${ }^{6}$ A study conducted by Bailey and Turner $^{3}$ showed metformin decreased $\mathrm{HbA} 1 \mathrm{c}$ by $1-1.5 \%$, depends on the HbA1c baseline level and patient tolerance, although gastrointestinal adverse effects occurred quite often at the beginning of the therapy. Hypoglycemia and lactic acidosis are seldom found in treatment with metformin, but in patients with renal insufficiency, adverse event monitoring needs to be conducted more closely.

Aside from the beneficial effect of metformin in improving glycemic control, treatment with metformin is usually inadequate to achieve metabolic control expected. Glycemic control often decreases in patients treated with metformin. This is the indication for an addition of a second drug. Sulphonylurea is the most common agent used as a combination, due to its mechanism of action in stimulating insulin secretion, that supports metformin mechanism of action in increasing insulin sensitivity. Other treatment combinations include combinations with thiazolidinediones and insulin. ${ }^{7}$ However, the combination with sulphonylurea and thiazolidinediones also lead to adverse effects. Sulphonylurea increases hypoglycemia 
risk and thiazolidinediones increase body weight, cardiovascular risk, and bone fractures in women. ${ }^{8,9}$ This article summarizes the experience in using a combination of metformin and DPP-4 inhibitors.

\section{DISCUSSION}

\section{Dipentidyl peptiase-4 inhibition as the target for T2DM treatment}

The basis for using DPP-4 inhibitors as the treatment for T2DM has been described in $1998 .{ }^{10}$ The study showed that DPP4 inhibitors caused an improvement in metabolic control by decreasing fasting and postprandial glucose level and decreasing HbAlc level after 4 weeks of treatment. ${ }^{11}$ The improvement in glycemic control by DPP-4 inhibitors has been confirmed by many studies with other components and now several DPP-4 inhibitors are developed. Most studies used vildagliptin and sitagliptin which are the active oral components that efficiently inhibits DPP-4 activity. ${ }^{12}$ Both components inhibit plasma DPP-4 activity for more than 16 hours after ingestion, therefore both agents can be given twice daily. Furthermore, both show improvement in glycemic control when they are used as combination therapy with metformin and thiazolidinediones. ${ }^{13}$ The important feature is that DPP-inhibitors are safe and well-tolerated so that they can be used as a treatment for T2DM.

\section{Rationale for combining metformin and DPP-inhibitors}

Type 2 diabetes mellitus occurs when insulin secretion is not comparable with the insulin resistance. ${ }^{14}$ With the increase in glucagon level, this will increase glucose degradation by the liver and increase the fasting glucose level. ${ }^{15}$ Metformin acts mainly by decreasing glucose production from the liver and improving insulin sensitivity in the liver and muscle, while DPP-4 inhibitors act by increasing GLP-1 level so that they stimulate insulin secretion and inhibit glucagon secretion. Metformin also increases the GLP-1 level, that potentially increases the synergistic effect with DPP-4 inhibitors. Mechanism of metformin in increasing GLP1 is not clear; several theories associated it with the DPP-4 inhibition, ${ }^{16}$ several others did not find the effect of metformin on DPP-4 activity. ${ }^{17}$ Recent studies showed that metformin stimulated GLP-1 secretion from the intestine. ${ }^{18}$ From the aspect of the mechanism of action, it is effective to combine metformin and DPP-4 inhibitors.

Another important feature is that the combination does not change the pharmacokinetics, as shown by sitagliptin, which furthermore supports the combination of both drugs.

\section{Randomized clinical trial vildagliptin as add-on therapy to metformin}

Several studies reported the use of a combination of DPP-inhibitors and metformin. The first study was conducted for 52 weeks, evaluating vildagliptin $50 \mathrm{mg}$ or placebo added to metformin therapy (1.5-3 g per day) in patients with mean baseline $\mathrm{HbA} 1 \mathrm{c}$ level of $7.8 \% .{ }^{19}$ Subjects mostly suffered from diabetes for 5.5 years and on average were treated with metformin for 29 months. The results showed that at 12 weeks initial treatment, the $\mathrm{HbAlc}$ level was decreased by $0.7 \%$ in the group given vildagliptin combined with metformin compared with the group given metformin alone. After 12 weeks, subjects were followed for 40 weeks. During that time, HbAlc increased $0.066 \% /$ month in patients on metformin therapy compared with an increase of $0.013 \% /$ month in patients given vildagliptin added to metformin. The difference in the 
change of HbA1c level between groups after 52 weeks of treatment was $1.1 \%$, showing a significant improvement in glycemic control with combination therapy of vildagliptin and metformin compared to treatment with metformin only. This study also showed that vildagliptin-metformin combination is safe and well-tolerated, and the overall adverse events were similar in both groups.

The second study conducted in 416 patients evaluated the addition of vildagliptin $50 \mathrm{mg}$ daily or twice daily to metformin therapy for the 24-week duration..$^{20}$ Patients in this study had diabetes with a mean duration of 6 years and have been treated with metformin for an average of 16 months, with average metformin dose of $2.1 \mathrm{~g}$ daily (inclusion criteria was $1.5 \mathrm{~g}$ daily). They had an average initial $\mathrm{HbAlc}$ level of $8.4 \%$. The BbA1c level was lowered by $0,5 \%$ in patients given vildagliptin $50 \mathrm{mg}$ daily and by $0.9 \%$ in patients given vildagliptin $100 \mathrm{mg}$ daily, both in combination with metformin compared to the increase of $0.2 \%$ in patients given placebo as add-on to metformin. The data were also analyzed in relation to how many patients who had improvement in glycemic control or had a failure in glycemic control. The analysis showed that in treatment with metformin only, $35 \%$ of the patients showed a failure in glycemic control and $31 \%$ did not have a significant change in glycemic control. In contrast, in patients given vildagliptin 50 mg combined with metformin, 38\% showed a significant increase in glycemic control and $29 \%$ had marked an increase in glycemic control (defined as a decrease in the $\mathrm{HbAlc}$ level of more than 1\%). The number of adverse events was not significantly different between groups. The only difference was the decrease in gastrointestinal adverse effects in subjects given vildagliptin $50 \mathrm{mg}$ in combination with metformin (9.6\%) compared with that given metformin only $(18.2 \%)$.
In conclusion, large studies showed that vildagliptin was well-tolerated if it was given as add-on treatment to metformin for 24 weeks duration and vildagliptin showed significant clinical improvement proven by the associated decrease in $\mathrm{HbA} 1 \mathrm{c}$ and fasting glucose levels.

\section{Randomized clinical trial sitagliptin as add-on therapy to metformin}

The first study on the effect of sitagliptin as add-on therapy in patients with inadequate glycemic control on metformin monotherapy is a 4-week study in 28 patients. ${ }^{21}$ Patients had diabetes for an average duration of 6.6 years, with average initial $\mathrm{HbA} 1 \mathrm{c}$ level of $7.7 \%$ and average fasting plasma glucose level of 8.4 $\mathrm{mmol} / \mathrm{L}$. In a long-term study on the effect of sitagliptin as add-on therapy to metformin in subjects with inadequate glycemic control, sitagliptin (100 mg once daily) was added to metformin (1.5 g daily) for 24 weeks. $^{22}$ A total of $47 \%$ of the patients treated with sitagliptin in combination with metformin achieved target $\mathrm{HbA} 1 \mathrm{c}$ of $7 \%$, while it was achieved by only $18 \%$ of subjects who were given metformin only. The study also showed that sitagliptin in combination with metformin decreased total cholesterol and triglyceride levels slightly, although significantly, while HDL-cholesterol level increased slightly. Body weight slightly decreased in both groups, with no difference between groups. The adverse events were also not different between groups. Therefore, showed that sitagliptin as add-on to metformin efficiently decreased HbAlc and fasting glucose level, and it was safe and well-tolerated. The efficacy and safety of sitagliptin, a highly selective DPP-4 inhibitor, when added to metformin monotherapy were examined in Japanese patients with T2DM. In this 52-week, an add-on to metformin study, 
149 patients were randomly assigned to receive sitagliptin $50 \mathrm{mg}$ or placebo once daily in a double-blind fashion for 12 weeks. Thereafter, all patients who completed the double-blind period of the study received open-label sitagliptin $50 \mathrm{mg}$ once daily for 40 weeks, with the investigator option of increasing sitagliptin to $100 \mathrm{mg}$ once daily for patients who met predefined glycemic thresholds. After 12 weeks of treatment, the mean change from baseline in $\mathrm{HbAl}$ significantly decreased with sitagliptin relative to placebo (between-group difference [95\% confidence interval $]=-0.7 \%[-0.9$ to -0.5$]$ $\mathrm{P}<0.001)$. At week 12, the mean changes in 2-h post-meal glucose $(-2.6 \mathrm{mmol} / \mathrm{L}$ $[-3.5$ to -1.7$])$ and fasting plasma glucose (-1.0 $\mathrm{mmol} / \mathrm{L}$ [-1.3 to -0.6$])$ also decreased significantly with sitagliptin relative to placebo ( $\mathrm{p}<0.001$ for both). Significant improvements from baseline in glycemic control were also observed in the open-label period through to week 52. There were no differences between treatment groups in the incidence of adverse events (AEs), including hypoglycemia and predefined gastrointestinal AEs (nausea, vomiting, and diarrhea) during the double-blind period, with similar findings in the open-label period. Over a period of 52 weeks, the addition of sitagliptin oncedaily to ongoing metformin therapy was efficacious and generally well tolerated in Japanese patients with T2DM. ${ }^{23}$

The present study evaluated the efficacy and tolerability of sitagliptin $100 \mathrm{mg}$ /day added to therapy with sulphonylurea and metformin. Patients with $\mathrm{HbA} 1 \mathrm{c} \geq 7.5 \%$ and $\leq 10.5 \%$ while on a sulphonylurea and metformin were randomized $1: 1$ to sitaglipti $100 \mathrm{mg} /$ day or placebo for 24 weeks. At Week 24, patients in the placebo group switched to pioglitazone $30 \mathrm{mg} /$ day and both groups continued treatment for another 30 weeks.Of 427 patients randomized, 339 (79.4\%) completed the study. At Week 24, significantly greater $(p<0.001)$ mean reductions from baseline were seen in the sitagliptin versus placebo group for $\mathrm{HbAlc}(-0.84 \%$ vs $-0.16 \%$, respectively), 2 -h post-meal glucose (-2.0 vs $-0.2 \mathrm{mmol} / \mathrm{L}$, respectively) and fasting plasma glucose (-0.7 vs $0.3 \mathrm{mmol} / \mathrm{L}$, respectively). At Week 54, improvements in glycemic control continued. At Week 24, the incidence of AEs was numerically greater with sitagliptin than placebo, primarily because of a higher incidence of hypoglycemia. At Week 54, the incidence of AEs was similar in both groups, primarily because of a higher incidence of hypoglycemia and edema in the placebo/ pioglitazone group after Week 24. The only meaningful change in body weight was an increase in the placebo/pioglitazone group at Week 54. In this study, sitagliptin $100 \mathrm{mg}$ /day was generally well tolerated and provided an improvement in glycemic control when added to the combination of sulphonylurea and metformin in patients with T2DM. ${ }^{24}$

\section{Randomized control trial saxagliptin as add-on therapy to metformin}

Recently, it was reported that DPP4 inhibitor saxagliptin increased glycemic control when it was added to metformin. ${ }^{25}$ The study included 743 patients with an average HbAlc level of $8.0 \%$ and average fasting glucose level of $9.8 \mathrm{mmol} / \mathrm{L}$ when they were treated with metformin alone. Saxagliptin has been added at the dose of $2.5,5$, or $10 \mathrm{mg}$ daily and this study also included a placebo arm. All patients continued with metformin. After 24 weeks of treatment, saxagliptin decreased $\mathrm{HbA} 1 \mathrm{c}$ level by $0.7 \%$ or $0.8 \%$ when it was adjusted for placebo in the three arms. Fasting glucose decreased by $0.9-1.1 \mathrm{mmol} / \mathrm{L}$. Similar to other DPP-4 inhibitors, saxagliptin 
is safe and well-tolerated when it is added to metformin.

Saxagliptinas add-on therapy to metformin showed significant clinical improvement in glycemic control. Average HbAlc level decreased by $0.65-1 \%$ from the baseline level of $7.8-8.4 \%$. Besides, this combination was tolerated and safe with similar adverse event profile with patients treated with placebo and metformin only.

To assess efficacy and safety of saxagliptin added to metformin versus placebo plus metformin in Asian patients with T2DM and inadequate glycemic control on metformin alone. Adults (HbA1c 7.0-10.0\%, on stable metformin $\geq 1500 \mathrm{mg} /$ day) were randomized $1: 1$ to saxagliptin $5 \mathrm{mg}$ daily plus metformin $(n=283)$ or placebo plus metformin $(n=287)$. The primary endpoint was a HbA1c change from baseline to Week 24. Saxagliptin plus metformin provided significant adjusted mean decreases versus placebo plus metformin $(\mathrm{p} \leq 0.0052)$ in HbAlc $(-0.78 \%$ versus $-0.37 \%)$, fasting plasma glucose $(-1.14 \mathrm{mmol} / \mathrm{L}$ versus $-0.58 \mathrm{mmol} / \mathrm{L}$ ), and postprandial glucose area under the curve from 0 to $180 \mathrm{~min}$ ( $-315 \mathrm{mmol} \mathrm{min} /$ Lversus $-160 \mathrm{mmol} \mathrm{min} / \mathrm{L}$ ). Significantly more saxagliptin-treated patients achieved a therapeutic glycemic response $\quad(\mathrm{HbA} 1 \mathrm{c}<7.0 \%) \quad(46.5 \%$ versus $30.5 \% ; p=0.0001)$. The proportion of patients experiencing adverse events (excluding hypoglycemia) was similar for saxagliptin plus metformin $(42.8 \%)$ versus placebo plus metformin (40.8\%). Hypoglycemic events were reported in $1.4 \%$ of patients in each group. Saxagliptin added to metformin significantly improved glycemic control and was well tolerated in Asian patients with T2DM who had inadequate glycemic control with metformin and diet and lifestyle modification. ${ }^{26}$
The aim of other study was to explore the efficacy and safety of saxagliptin in a large Chinese population with T2DM. In all, 1423 T2DM patients from 92 research centers, either drug naïve or uncontrolled by metformin, were enrolled in this singlearm cohort study; patients have treated with saxagliptin $5 \mathrm{mg}$ once daily for 24 weeks. The primary efficacy endpoint was the change from baseline in HbAlc at 24 weeks in the per-protocol analysis set. Secondary endpoints included the proportion of patients achieving $\mathrm{HbAlc}<7 \%$ and changes from baseline in fasting plasma glucose (FPG) and 2-h postprandial plasma glucose (PPG) concentrations at 24 weeks. Safety endpoints included adverse events (AEs) and the incidence of hypoglycemia.Among 1210 patients in the per-protocol analysis set, mean HbA1c, FPG and 2-h PPG decreased by $1.61 \pm 0.04 \%, 0.55 \pm 0.07 \mathrm{mmol} / \mathrm{L}$, and $2.83 \pm 0.27 \mathrm{mmol} / \mathrm{L}$, respectively, at week 24. The proportion of patients achieving HbAlc $<7 \%$ was $44.1 \%$. No new (previously unreported) AEs occurred. The incidence of serious AEs and hypoglycemia was low ( $1.8 \%$ and $1.2 \%$, respectively). There were no significant differences in efficacy endpoints in subgroup analyses by age, creatinine clearance, body mass index, or treatment background. In elderly patients ( $\geq 65$ years) and those with mild renal impairment (50 $<\mathrm{CCr} \leq 80 \mathrm{~mL} / \mathrm{min}$ ), the incidence of AEs was similar to that of the entire study population. Saxagliptin significantly improved glycemic control and was well tolerated in Chinese T2DM patients, including the elderly and patients with mild renal impairment. ${ }^{27,28}$

A randomized controlled clinical trial conducted to assess efficacy and safety of saxagliptin added to metformin versus placebo plus metformin in Asian patients with T2DM and inadequate glycemic control on metformin 
alone. Adults (HbA1c 7.0-10.0\%, on stable metformin $1500 \mathrm{mg} /$ day) were randomized 1:1 to saxagliptin $5 \mathrm{mg}$ daily plus metformin $(\mathrm{n}=283)$ or placebo plus metformin $(\mathrm{n}=287)$. The primary endpoint was a HbAlc change from baseline to Week 24. Saxagliptin plus metformin provided significant adjusted mean decreases versus placebo plus metformin ( $\mathrm{p}=0.0052)$ in HbA1c $(0.78 \%$ versus $0.37 \%)$, fasting plasma glucose $(1.14 \mathrm{mmol} / \mathrm{L}$ versus $0.58 \mathrm{mmol} / \mathrm{L}$ ), and postprandial glucose area under the curve from 0 to $180 \mathrm{~min}(315 \mathrm{mmol}$ $\mathrm{min} / \mathrm{L}$ versus $160 \mathrm{mmol} \mathrm{min} / \mathrm{L}$ ). Significantly more saxagliptin-treated patients achieved a therapeutic glycemic response $(\mathrm{HbA1c}<$ $7.0 \%)(46.5 \%$ versus $30.5 \% ; p=0.0001)$. The proportion of patients experiencing AEs (excluding hypoglycemia) was similar for saxagliptin plus metformin (42.8\%) versus placebo plus metformin (40.8\%). Hypoglycemic events were reported in $1.4 \%$ of patients in each group. Saxagliptin added to metformin significantly improved glycemic control and was well tolerated in Asian patients with T2DM who had inadequate glycemic control with metformin and diet and lifestyle modification.

\section{Randomized clinical trial linagliptin as add-on therapy to metformin}

A multicenter, randomized, placebocontrolled, double-blind, parallel-group study examined the efficacy and tolerability of linagliptin as treatment adjunctive to metformin in patients T2DM. Eligible participants were aged 18 to 80 years (mean, 56.5 years) with a BMI of $40 \mathrm{~kg} / \mathrm{m} 2$ (mean baseline BMI, $29.9 \mathrm{~kg} / \mathrm{m} 2$ ) and were receiving metformin at a dosage of $1500 \mathrm{mg}$ /day (or maximum tolerated dose) with or without an additional oral antidiabetic (OAD) other than a thiazolidinedione. Eligible participants receiving metformin monotherapy had a baseline $\mathrm{HbA} 1 \mathrm{c}$ of $7.0 \%$ to $10.0 \%$; in those taking metformin plus an OAD, the $\mathrm{HbA} 1 \mathrm{c}$ range for eligibility was $6.5 \%$ to $9.0 \%$. In participants receiving an OAD in addition to metformin at screening, the additional OAD was discontinued, and metformin $1500 \mathrm{mg}$ / day was continued throughout a 6-week washout period prior to randomization. All participants completed a 2-week placebo runin phase before random assignment to either linagliptin $5 \mathrm{mg} /$ day $(\mathrm{n}=524)$ or placebo $(n=177)$. All participants were required to have an $\mathrm{HbA} 1 \mathrm{c}$ of 7.0 to $10.0 \%$ at randomization. The primary end point was changed in $\mathrm{HbAlc}$ from baseline to 24 weeks of treatment. The mean adjusted change from baseline in $\mathrm{HbA} 1 \mathrm{c}$ in the linagliptin group was $0.49 \%$ compared with an increase of $0.15 \%$ in the placebo group (treatment difference $=0.64 \% ; 95 \%$ $\mathrm{CI}=0.78$ to $0.50 ; \mathrm{p}=0.0001$ ), with $26 \%$ and $9 \%$ of participants in the linagliptin and placebo groups, respectively, achieving an $\mathrm{HbAlc}$ $7.0 \%$ at 24 weeks. Linagliptin treatment was associated with significant decreases from baseline in FPG (10.6 mg/dL vs $10.5 \mathrm{mg}$ / $\mathrm{dL} ; \mathrm{p}=0.0001$ ) and 2-hour PPG (48.6 mg/ $\mathrm{dL}$ vs $18 \mathrm{mg} / \mathrm{dL}$; $\mathrm{p}=0.0001$ ) compared with placebo. Neither treatment group realized a statistically significant decrease in mean weight (changes from baseline, $0.4 \mathrm{~kg}$ and 0.5 $\mathrm{kg}$ with linagliptin and placebo). ${ }^{29}$

To evaluate the efficacy/safety of DPP4 inhibitor, linagliptin, in subjects with insufficiently controlled T2DM, and factors influencing treatment response. Pooled analysis of data from 2258 subjects in three 24-week phase III, randomized, placebocontrolled, parallel-group studies, who received oral linagliptin ( $5 \mathrm{mg}$ /day) or placebo as monotherapy, added-on to metformin, or added-on to metformin plus a sulphonylurea was performed. Among 388 subjects with $\mathrm{HbAlc} \geq 9.0 \%$, adjusted mean baseline $\mathrm{HbA} 1 \mathrm{c}$ 
(9.4\% both groups) declined to $8.3 \%$ in linagliptin group and $9.1 \%$ in the placebo group at 24 weeks $(p=0.0001)$ and adjusted mean change from baseline was $1.2 \%$ (vs. $0.4 \%$, placebo). Linagliptin significantly lowered fasting plasma glucose levels vs. placebo (1.6 $\mathrm{mmol} / \mathrm{L}$ vs. $0.4 \mathrm{mmol} / \mathrm{L})$; treatment difference, $1.1 \mathrm{mmol} / \mathrm{L}(95 \% \mathrm{CI}=-1.7-0.5)$. Treatment and washout of previous OAD were the only factors to independently affect $\mathrm{HbA} 1 \mathrm{c}$ change at week 24. Adverse event rates were similar for linagliptin $(61.9 \%)$ and placebo $(62.7 \%)$. Hypoglycemia was rare with linagliptin addon to metformin $(\leq 1 \%)$ and increased when linagliptin was added to metformin plus sulphonylurea (linagliptin, $17.9 \%$ vs. placebo, $8.3 \%$ ). Linagliptin was an effective, welltolerated treatment in subjects with T2DM and insufficient glycemic control, as added-on to metformin/metformin plus sulphonylurea. ${ }^{30}$

\section{Meta-analysis of DPP-4 inhibitors as add- on to metformin}

Meta-analysis was performed to provide an update on the efficacy and safety of DPP4 inhibitors and metformin as combination therapy in patients with T2DM. Meta-analysis was performed to provide an update on the efficacy and safety of DPP-4 inhibitors and metformin as combination therapy in patients with T2DM. They were RCTs comparing DPP-4 inhibitors (i.e alogliptin, dutogliptin, linagliptin, saxagliptin, sitagliptin, vildagliptin) plus metformin as combination therapy, duration of treatment was $\geq 12$ weeks and reported data on $\mathrm{HbAlc}$ change, FPG change, weight change, hypoglycaemia or gastrointestinal AEs. A total of eight RCTs were included. Compared with metformin monotherapy, DPP-4 inhibitors plus metformin as combination therapy was associated with higher reduction in $\mathrm{HbA} 1 \mathrm{c}$ level $(\mathrm{MD}=-0.49$;
$95 \% \mathrm{CI}=-0.57--0.40 ; \mathrm{p}=0.00001)$, higher reduction in FPG level $(\mathrm{MD}=-0.80 ; 95 \% \mathrm{CI}$ $=-0.87--0.74 ; \mathrm{p}=0.00001)$, lower weight loss $(\mathrm{MD}=0.44 ; 95 \% \mathrm{CI}=0.22-0.67 ; \mathrm{p}=$ $0.0001)$; nor the higher risk of hypoglycaemia $(\mathrm{RR}=1.04 ; 95 \% \mathrm{CI}=0.72-1.50 ; \mathrm{p}=0.82)$, nor the prolonged risk of gastrointestinal AEs $(\mathrm{RR}=0.98 ; 95 \% \mathrm{CI}=0.88-1.10 ; \mathrm{p}=0.77)$. Dipeptidyl peptidase-4 inhibitors, which are safe and effective in controlling the blood glucose. It could be a credible alternative for T2DM patients who, for some reason, cannot use metformin. ${ }^{31}$

\section{CONCLUSION}

Dipeptidyl peptidase-4 inhibitors have been proven to be antidiabetic when they are given in combination with metformin. This novel strategy in treating T2DM is expected to increase the future value in T2DM treatment. Overall experience shows that this novel strategy is efficient, well-tolerated, and safe with minimal risk for hypoglycemic events. Furthermore, the combination of DPP-4 inhibitors and metformin is safe and well-tolerated. Therefore, the indication for treatment with DPP-inhibitors is as addon therapy to metformin in T2DM patients uncontrolled with metformin.

\section{ACKNOWLEDGMENT}

I am very grateful to my colleague Alfi Yasmina, MD, MSc, MMedEd, PhD, from Lambung Mangkurat University, Banjarmasin, Indonesia and want to express my acknowledgment because it was possible due to her kindly help in the English correction.

\section{REFERENCES}

1. Stratton IM, Adler AI, Neil HA, Matthews DR, Manley SE, Cull CA, et al. Association 
of glycemia with macrovascular and microvascular complications of type 2 diabetes (UKPDS 35): prospective observational study. BrMed J 2000; 321:405-1 https://doi.org/10.1136/bmj.321.7258.405

2. Inzucchi SE. Oral antihyperglycemic therapy for type 2 diabetes: scientific review. JAMA 2002; 287:360-72. https://doi.org/10.1001/ jama.287.3.360

3. Bailey CJ \& Turner RC. Metformin. N Engl J Med 1996; 334:574-9. https://doi. org/10.1056/NEJM199602293340906

4. Ginnarelli R, Aragona M, Coppelli A, Del Prato S. Reducing insulin resistance with metformin: the evidence today. Diabetes Metab 2003; 29:6S28-35.

5. Ikeda T, Iwata K, Murakami H. Inhibitory effect of metformin on intestinal glucose absorption in the perfused rat intestine. Biochem Biopharmacol 2000; 59:887-90. https://doi.org/10.1016/S0006-2952(99) 00396-2

6. Mannucci E, Pierazzuoli E, Ognibene A, Cremasco F, Bardini G, Mencucci A, et al. Effect of metformin on glucagon-like peptide 1 (GLP-1) and leptin levels in obese nondiabetic subjects. Diabetes Care 2001; 24:489-94. https://doi.org/10.2337/diacare.24.3.489

7. Hundal RS \& Inzucchi SE. Metformin: new understandings, new uses. Drugs 2003; 63:1879-94. https://doi. org/10.2165/00003495-200363180-00001

8. Green JB \& Feinglos MN. Are sulphonylureas passé? Curr Diabet Rep 2007; 6:373-7.

9. Kahn SE, Haffner SM, Helse MA, Herman WH, Holman RR, Jones NP, et al. Glycemic durability of rosiglitazone, metformin, or glyburide monotherapy. N Engl J Med 2006; 355:2427-43. https://doi.org/10.1056/ NEJMoa066224

10. Holst JJ \& Deacon CF. Inhibition of the activity of dipeptidyl-peptidase IV as a treatment for type 2 diabetes. Diabetes 1998; 47:1663-70. https://doi.org/10.2337/diabetes.47.11.1663

11. Ahrén B, Simonsson E, Larsson H, LandinOlsson M, Torgeirsson H, Jansson PA, et al. Inhibition of dipeptidyl peptidase IV improves metabolic control over a 4 week study period in type 2 diabetes. Diabetes Care 2002; 25:869-75 https://doi.org/10.2337/ diacare.25.5.869

12. Ahrén B. Vildagliptin: an inhibitor of dipeptidyl peptidase-4 with antidiabetic properties. ExpOpin Invest Drugs 2006; 15:431-42. https://doi.org/10.1517/ 13543784.15.4.431

13. Gallwitz B. Review of sitagliptin phosphate: a novel treatment for type 2 diabetes. Vasc Health Risk Manag 2007; 3:203-10. https:// doi.org/10.2147/ vhrm.2007.3.2.203

14. DeFronzo RA. Pathogenesis of type 2 diabetes mellitus. Med Clin North Am 2004 88:787-835. https://doi.org/10.1016/j. mcna.2004.04.013

15. Dunning BE, Foley J, Ahrén B. Alpha-cell function in health and disease: influence of GLP-1. Diabetologia 2005; 48:1700-13. https://doi.org/10.1007/s00125-005-1878-0

16. Lindsay JR, Duffy NA, McKillop AM, Ardill J, O'Harte FPM, Flatt PR, et al. Inhibition of dipeptidyl peptidase IV activity by oral metformin in type 2 diabetes. Diabet Med 2005; 22:654-7. https://doi.org/10.1111/ j.1464-5491.2005.01461.x

17. Hinke SA, Kuhn-Wache $K$, Hoffman T, Pederson RA, McIntosh CHS, Demuth HU. Metformin effect on dipeptidyl peptidase IV degradation of glucagon-like peptide-1. BiochemBiophys Res Commun 2002; 291:1302-8. https://doi.org/10.1006/ bbrc. 2002.6607

18. Migoya EM, Miller J, Larson P, Tanen M, Hilliard D, Deacon C, et al. Sitagliptin, a selective DPP-4 inhibitor, and metformin have complementary effects to increase 
active GLP-1 concentrations. Diabetes 2007; 56(Supp11): A74.

19. Ahrén B, Gomis R, Standl E, Mills D, Schweizer A. Twelve- and 52-week efficacy of the dipeptidyl peptidase IV inhibitor LAF237 in metformin-treated patients with type 2 diabetes. Diabetes Care 2004a; 27:2874-80. https://doi.org/10.2337/diacare.27.12.2874

20. Bosi E, Camisasca RP, Collober C, Rochotte E, Garber AJ. Effects of vildagliptin on glucose control over 24 weeks in patients with type 2 diabetes inadequately controlled with metformin. Diabetes Care 2007; 30:890-5. https://doi.org/10.2337/dc06-1732

21. Brazg R, Xu L, Dalla Man C, Cobelli C, Thomas K, Stein PP. Effect of adding sitagliptin, a dipeptidyl peptidase-4 inhibitor, to metformin on 24-h glycemic control and $\beta$-cell function in patients with type 2 diabetes. Diabetes Obes Metab 2007; 9:186-93. https:// doi.org/10.1111/j.1463-1326.2006.00691.x

22. Charbonnel B, Karasik A, Liu J, Wu M, Meininger G, Sitagliptin Study 020 Group. Efficacy and safety of the dipeptidyl peptidase-4 inhibitor sitagliptin added to ongoing metformin therapy in patients with type 2 diabetes inadequately controlled with metformin alone. Diabetes Care 2006; 29:2638-43. https://doi.org/10.2337/dc060706

23. Kadowaki T, Tajima N, Odawara M, Nishii M, Taniguchi T, Ferreira JC. Addition of sitagliptin to ongoing metformin monotherapy improves glycemic control in Japanese patients with type 2 diabetes over 52 weeks. J Diabetes Investig 2013; 4(2):174-81. https://doi.org/10.1111/jdi.12001

24. Moses RG, Round E, Shentu Y, Golm GT, O'Neill EA, Gantz I, et al. A randomized clinical trial evaluating the safety and efficacy of sitagliptin added to the combination of sulfonylurea and metformin in patients with type 2 diabetes mellitus and inadequate glycemic control. J Diabetes 2016; 8(5):70111. https://doi.org/10.1111/1753-0407.12351

25. DeFronzo R, Hissa M, Blauwet MB, Chen RS. Saxagliptin added to metformin improves glycemic control in patients with type 2 diabetes. Diabetes 2007; 56(Suppl 1):A74.

26. Yang W, Pan CY, Tou C, Zhao J, GauseNilsson I. Efficacy and safety of saxagliptin added to metformin in Asian people with type 2 diabetes mellitus: A randomized controlled trial. Diabetes Research and Clinical Practice 2011; 94(2):217-224. https://doi.org/10.1016/j.diabres.2011.07.035

27. White JL, Buchanan P, Li J, Frederich R. A randomized controlled trial of the efficacy and safety of twice-daily saxagliptin plus metformin combination therapy in patients with type 2 diabetes and inadequate glycemic control on metformin monotherapy. BMC Endocr Disord 2014; 14: 17. https://doi. org/10.1186/1472-6823-14-17

28. Gu W, Liang L, Wang S, Wang Y, Wu Y, Tian $\mathrm{J}$, et al. Efficacy and safety of saxagliptin monotherapy or added to metformin in Chinese patients with type 2 diabetes mellitus: results from the 24-week, post-marketing SUNSHINE study. J Diabetes 2016; 8(6):809-815. https://doi.org/10.1111/17530407.12360

29. Taskinen MR, Rosenstock J, Tamminen I, Kubiak R, Patel S, Dugi KA, et al. Safety and efficacy of linagliptin as add-on therapy to metformin in patients with type 2 diabetes: a randomized, double-blind, placebocontrolled study. Diabetes Obes Metab 2011;13(1):65-74.https://doi.org/10.1111/ j.1463-1326.2010.01326.x

30. Owens DR, Swallow R, Dugi KA and Woerle HJ. Efficacy and safety of linagliptin in persons with Type 2 diabetes inadequately controlled by a combination of metformin and sulphonylurea: a 24-week randomized study. Diabet. Med 2011; 28, 1352-1361 
Kristin, Combination treatment for type 2 diabetes mellitus (T2DM): dipeptidyl peptidase-4 inhibitors (DPP-4) and metformin

https://doi.org/10.1111/j.1464-5491. 2011. 03387.x

31. Pfutzner A, Paz-Pacheco E, Allen E, Frederich R, Chen R; CV181039 Investigators. Initial combination therapy "with saxagliptin and metformin provides sustained glycaemic control and is well tolerated for up to 76 weeks. Diabetes Obes Metab 2011; 13: $567-$ 576. https://doi.org/10.1111/j.1463-1326. 2011.01385.x 